\title{
Alkaline phosphatase and disaccharidase activity in Barrett's columnar lined esophagus
}

\author{
S.N. Sullivan FRCP(C), R. J. Dariwish MSc, M. Troster FRCP(C)
}

ABSTRACT: Esophageal mucosal biopsies of 15 patients with normal squamous epithelium, 11 with inflamed squamous epithelium and 23 with Barrett's columnar lined esophagus were assayed for alkaline phosphatase and disaccharidase activity. Seven of the patients with Barrett's esophagus had alkaline phosphatase activity greater than three standard deviations above the mean of the 15 patients with normal squamous epithelium. Five of these seven also had disaccharidase activity three standard deviations or greater above normal. One patient with esophagitis, but without columnar epithelium, had a small increase in alkaline phosphatase and disaccharidase activity. The production of biochemical markers of small intestinal structure may be another indicator of the pluripotential nature of Barrett's epithelium. Can J Gastroenterol 1988; 2(1): 15-17

Key Words: Alkaline phosphatase, Barrett's esophagus, Columnar lined esophagus, Dissacharidase

$\mathrm{T}$ He metaplastic Columnar epithelium of a Barrett's esophagus is believed to arise as a result of chronic gastroesophageal reflux. The pluripotential nature of this epithelium is evidenced not only by the description of at least three histologic types (gastric fundic, cardiac or junctional, and specialized or intestinal) but also by the demonstration that cells of this epithelium may produce acid, mucins, pepsin and pepsinogens, serotonin and regulatory peptides, and lysosomal enzymes (1-7). The description of small intestinal-like microvilli on some of the cells (8) prompted the authors to investigate whether these cells might also produce other markers of small intestinal structure - alkaline phosphatase and disaccharidases. The alkaline phosphatase and disaccharidase activity of esophageal mucosa from patients with esophagitis, Barrett's esophagus and normal squamous mucosa were studied prospectively.
Departments of Medicine and Pathology, Victoria Hospital, London, Ontario

Correspondence: Dr Stephen N. Sullivan, Department of Medicine, Victoria Hospital, South Street, London, Ontario N6A 4G5

Received for publication July 20, 1987. Accepted September 18, 1987

\section{PATIENTS AND METHODS}

Directed endoscopic biopsies of the distal esophagus were obtained from 23 patients with Barrett's esophagus undergoing cancer surveillance and from 26 patients undergoing routine diagnostic endoscopy for chest pain, heartburn or dysphagia. In addition to the biopsies obtained for histological identification of dysplasia or confirmation of endoscopic findings, one or two further biopsies were obtained for biochemical assay. If the esophagus was endoscopically normal or showed only mild erythema, biopsies were obtained from the distal $5 \mathrm{~cm}$. If the endoscopic impression was that of esophagitis the biopsies were obtained from obviously inflamed, eroded or ulcerated areas. If the patient had a Barrett's esophagus the biopsies were obtained from a site near the upper end of the columnar epithelium.

Tissue samples for biochemical analysis were immediately frozen until assayed for disaccharidases and alkaline phosphatase. The biopsies were weighed and diluted in chilled, deionized water to a concentration of no less than $1 \mathrm{mg} / \mathrm{mL}$. They were homogenized and centrifuged; the supernatant was saved for assay. Maltase, sucrase and lactase activities were 
measured by the Tris-glucose oxidase (TGO) method of Dahlquist (9). This detects the colour change due to the oxidation of 0 -dianisidine by peroxidase in the presence of hydrogen peroxide which is the end product of disaccharidase activity on sugar substrates. The method calls for the addition of $0.1 \mathrm{~mL}$ aliquots of homogenized tissue supernatant to tubes containing $0.1 \mathrm{~g}$ of maltose, sucrose and lactose. The tubes are incubated for $60 \mathrm{mins}$ at $37^{\circ} \mathrm{C}$ in a water bath.

The enzyme reaction is stopped by boiling and $0.5 \mathrm{~mL}$ aliquots from the tubes are mixed with $3.0 \mathrm{~mL}$ of TGO reagent (Sigma type V; 2000 units per $\mathrm{mL}$ of reagent). This mixture is incubated for 60 mins at $37^{\circ} \mathrm{C}$ after which the optical density is measured at 420 $\mathrm{nm}$. Using a graph obtained for a glucose standard of optical density against micrograms of glucose the amount of glucose release in each test sample is derived. The disaccharidase activity is calculated by dividing the micrograms of glucose released by 540 in the case of lactose and sucrose, or 1080 for maltose and dividing the answer by the concentration of homogenized tissue ( 1 unit $=\mu \mathrm{g}$ glucose/ molecular weight of substrate/h).

For the assay of alkaline phosphatase $0.1 \mathrm{~mL}$ aliquots of homogenate supernatant are added to tubes containing $1 \mathrm{~mL}$ of p-nitrophenylphosphate (Sigma) in glycerin buffer ( $\mathrm{pH} 10)$. Deionized water is used for the blank. The tubes are incubated for 10 mins at $37^{\circ} \mathrm{C}$ after which the reaction is stopped with $10 \mathrm{~mL}$ of 0.02 $\mathrm{N}$ sodium hydroxide. The optical density of the test sample is read against the blank at $410 \mathrm{~nm}$. Phosphatase activity is determined from a standard curve of optical density versus dilutions of p-nitrophenolate and expressed as international units/g of mucosa (10).

All biopsies were reviewed by one pathologist (MT) who had no knowledge of the clinical history or endoscopic findings. The biopsies were reported as normal; as showing squamous epithelium with esophagitis, according to the criteria of Ismail-Beigi et al (11); or as showing columnar

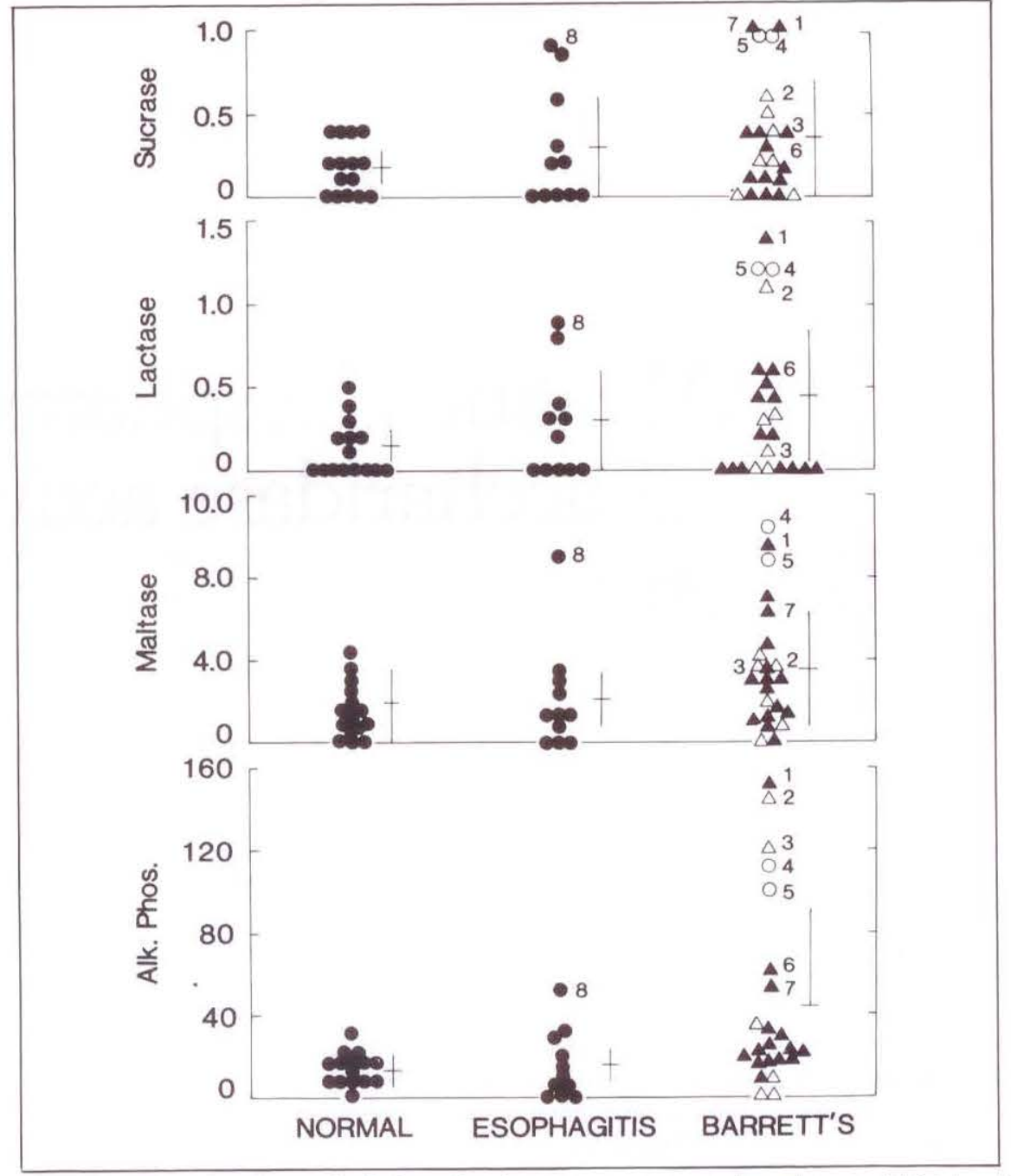

Figure 1) Disaccharidase and alkaline phosphatase activity in esophageal mucosal biopsies of patients with normal squamous epithelium (15 patients), esophagitis (11) and Barrett's esophagus (23). Mean $\pm 1 S D$. The numbers 1 to 8 identify individual patients. $\triangle$ Intestinal; $\mathbf{\Delta}$ Cardiac; Fundic

epithelium with or without inflammation. If the epithelium was columnar it was further classified as fundic, cardiac or intestinal.

Statistical analysis was by unpaired $t$ test with $\mathrm{P}<0.05$ taken as the level of significance.

\section{RESULTS}

The esophageal mucosa of the $15 \mathrm{pa}$ tients with histologically normal epithelium had low levels of alkaline phosphatase and disaccharidase activity (Figure 1). There were no significant differences in enzyme activity between the normal subjects and the patients with inflamed squamous epithelium; however, one patient (number 8) with esophagitis was an outlier. He had increased levels of all three disaccharidases and alkaline phosphatase.

Compared to the subjects with normal epithelium the patients with Barrett's esophagus had significant increases in lactase $(\mathrm{P}<0.005)$, sucrase $(\mathrm{P}<0.025)$, maltase $(\mathrm{P}<0.05)$ and alkaline phosphatase $(\mathrm{P}<0.005)$. Seven of the 23 patients with Barrett's epithelium had alkaline phosphatase activity greater than three standard deviations above the mean activity of the subjects with normal epithelium. Five of these seven (patients 1, 2, 4, 5 and 7) also had enzyme activity of one or more of the disaccharidases three standard deviations or greater than the mean enzyme activity of normal epithelium. There 
was no correlation between the histologic type of Barrett's epithelium (intestinal, cardiac or fundic) and alkaline phosphatase or disaccharidase activity.

Compared to the subjects with inflamed squamous epithelium the patients with Barrett's esophagus had a significant increase in the mean alkaline phosphatase activity $(\mathrm{P}<0.025)$ but there were no significant increases in mean disaccharidase activity.

\section{DISCUSSION}

The columnar epithelium of a Barrett's esophagus is characterized by marked heterogeneity. Its cell types may include columnar mucous cells, mucous gland cells, goblet cells, chief and parietal cells, Paneth cells and neuroendocrine cells. They may produce or contain acid, a variety of mucins, pepsin and pepsinogens, serotonin and regulatory peptides and lysosomal enzymes. In this study it was shown that the columnar cells of a Barrett's esophagus may occasionally have disaccharidase and alkaline phosphatase a@ivity.

The authors found only one other study looking for disaccharidase activity in Barrett's esophagus. Berenson et al (12) were not able to identify disaccharidase activity in Barrett's epithelium; however, they studied

\section{REFERENCES}

1.Paull A, Trier JS, Dalton MD, Camp RC, Loeb P, Goyal RK. The histologic spectrum of Barrett's esophagus. NEngl J Med 1976; 295: 476-80. 2. Hershfield NB, Lind JF, Hildes JA, McMorris LS. Secretory function of Barrett's epithelium. Gut 1965; 6: 535-9.

3.Zwas F, Shields HM, Doos WG, et al. Scanning electron microscopy of Barrett's epithelium and its correlation with light microscopy and mucin stains. Gastroenterology 1986; 90: 1932-41.

4. Mangla JC, Schenk EA, Desbaillets L, Guarasci G, Kubasik P, Turner MD. Pepsin secretion, pepsinogen, and gastrin in "Barrett's Esophagus".

Gastroenterology 1976; 70: 669-76.

5. Schreiber DS, Apstein M, Hermos JA. Paneth cells in Barrett's esophagus. only four patients. In the present study only five of the 23 patients with Barrett's esophagus had elevations in any of the three disaccharidases measured.

The authors are aware of no other study demonstrating elevated levels of alkaline phosphatase activity in Barrett's epithelium and can find only one study of alkaline phosphatase activity in patients with esophagitis, but without Barrett's epithelium. Hopwood et al (13) found higher levels of alkaline phosphatase activity in patients with esophagitis compared to normal controls but their results could not be confirmed by the present authors.

When the present study was started, the authors anticipated that disaccharidase and alkaline phosphatase activity might be found in columnar epithelium which was classified as intestinal or specialized as this type of epithelium frequently has intestinallike microvilli. Such was not the case and no correlation was found between the histologic classification of the Barrett's epithelium and the enzyme activity. There is no good explanation for this. Early studies suggested that the columnar epithelium of Barrett's esophagus was arranged in zones with the specialized columnar epithelium most proximal and the gastric fundic epithelium most distal but it now appears that such is not always true

Gastroenterology 1978; 74: 1302-4.

6. Buchan AMJ, Grant S, Freeman H. Regulatory peptide-containing cells in Barrett's esophagus. Gastroenterology 1983; 84: 1116. (abst)

7. Berenson MM, Herbst JJ, Freston JW. Esophageal columnar epithelial $\beta$. galactosidase and $\beta$-glucuronidase. Gastroenterology 1975; 68: 1417-20.

8. Mangla JC, Lee CS. Scanning electron microscopy of Barrett's esophageal mucosa. Gastrointest Endosc 1979; 25: $92-4$

9. Dahlquist A. Method for assay of intestinal disaccharidases. Anal Biochem 1964; $7: 18-25$.

10. Bessey OA, Lowry OH, Brock MJ. A method for the rapid determination of alkaline phosphatase with five cubic millimeters of serum. J Biol Chem 1946; 164: 321-9.
$(14,15)$. The different types of epithelium may be intermixed with tongues or islands of one protruding into another. A recent scanning electron micrographic study shows that individual cells of different types may even be juxtaposed (3). The tissue samples obtained by endoscopic biopsy are small and it is not practical to divide a single sample. Therefore, the biopsies upon which the histologic classification was made were not the same biopsies assayed for enzyme activity. Although it was attempted to obtain biopsies from immediately adjacent areas, endoscopists know that accurately directed biopsy in the esophagus is not always easy, especially when previous biopsies have led to bleeding. Therefore, the lack of correlation between histologic classification and enzyme activity is not completely unexpected.

The authors conclude that in some patients with Barrett's esophagus the columnar epithelium of the esophagus, like the epithelium of the small intestine, has the ability to produce alkaline phosphatase and disaccharidases. Those epithelia with high levels of alkaline phosphatase are likely also to contain high levels of disaccharidase activity. This is yet another example of the pluripotential nature of a Barrett's epithelium.

11. Ismail-Beigi F, Horton PF, Pope CE II. Histologic consequences of gastroesophageal reflux in man. Gastroenterology 1970; 58: 163-74.

12. Berenson MM, Herbst JJ, Freston JW. Enzyme and ultrastructural characteristics of esophageal columnar epithelium. Dig Dis 1974; 19: 895-907.

13. Hopwood D, Ross PE, Logan KR, Nicholson G, Bouchier IAD. Changes in enzyme activity in normal and histologically inflamed oesophageal epithelium. Gut 1978; 20: 769-74.

14. Rothery GA, Patterson JE, Stoddard CJ, Day DW. Histological and histochemical changes in the columnar lined (Barrett's) oesophagus. Gut 1986; 27: 1062-8.

15.Spechler SJ, Goyal RK. Barrett's esophagus. N Engl J Med 1986; 315: 362-71. 


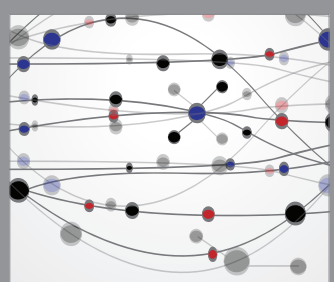

The Scientific World Journal
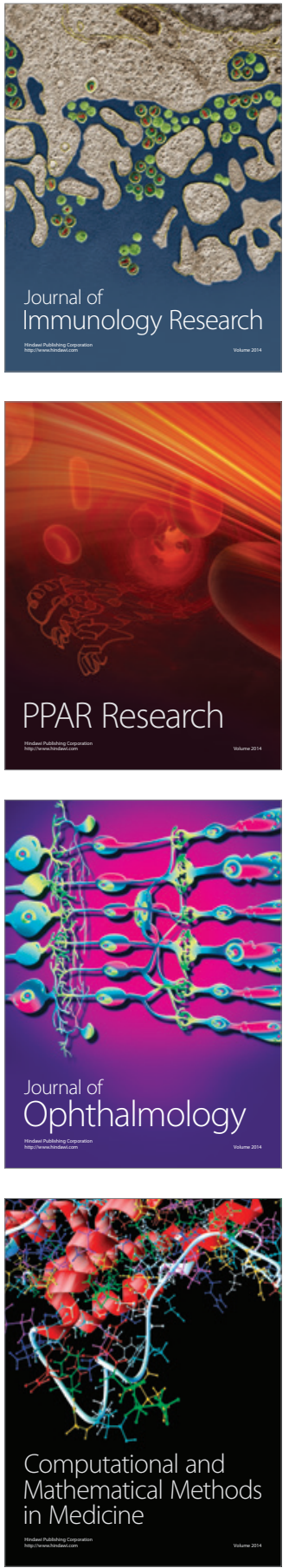

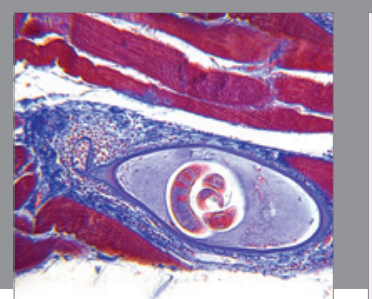

Gastroenterology Research and Practice

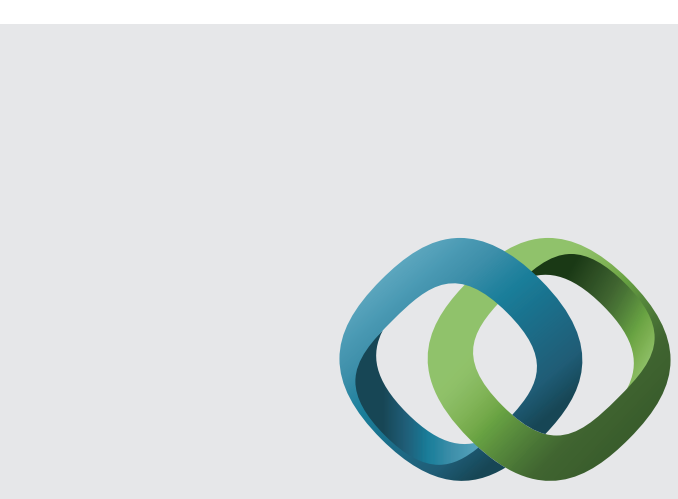

\section{Hindawi}

Submit your manuscripts at

http://www.hindawi.com
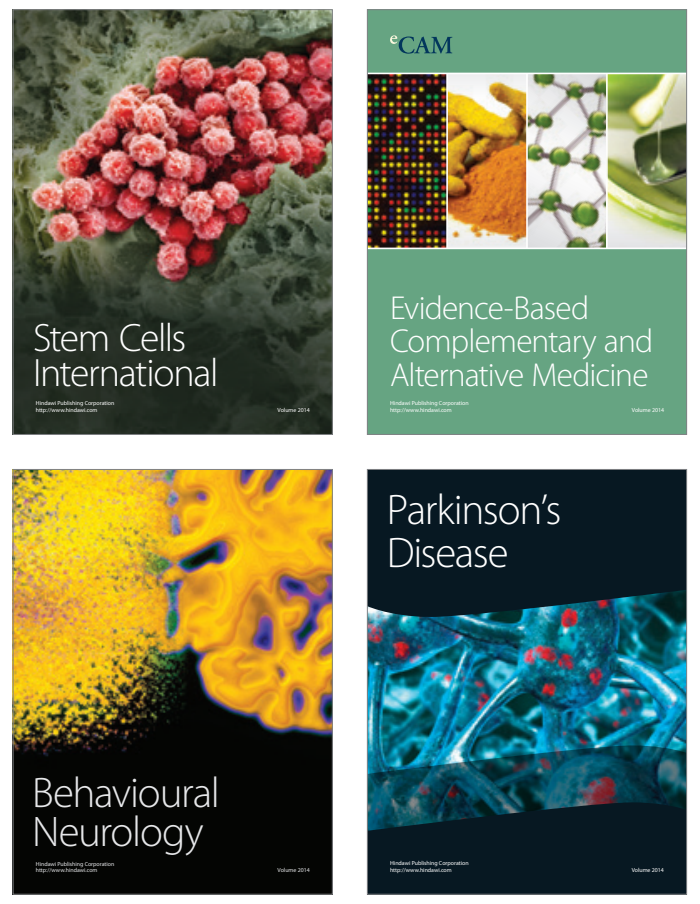
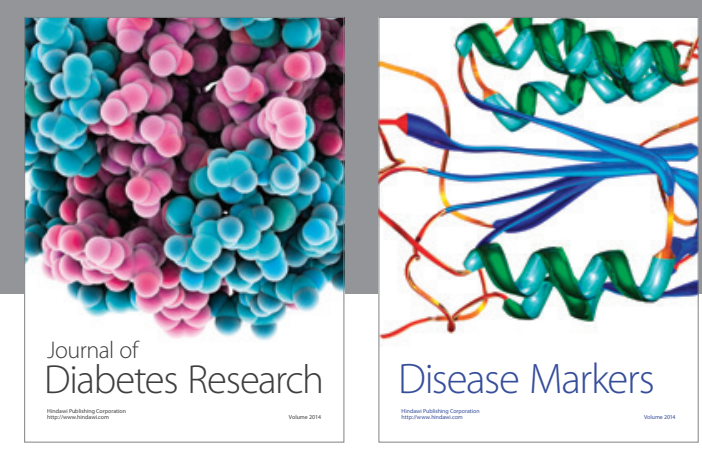

Disease Markers
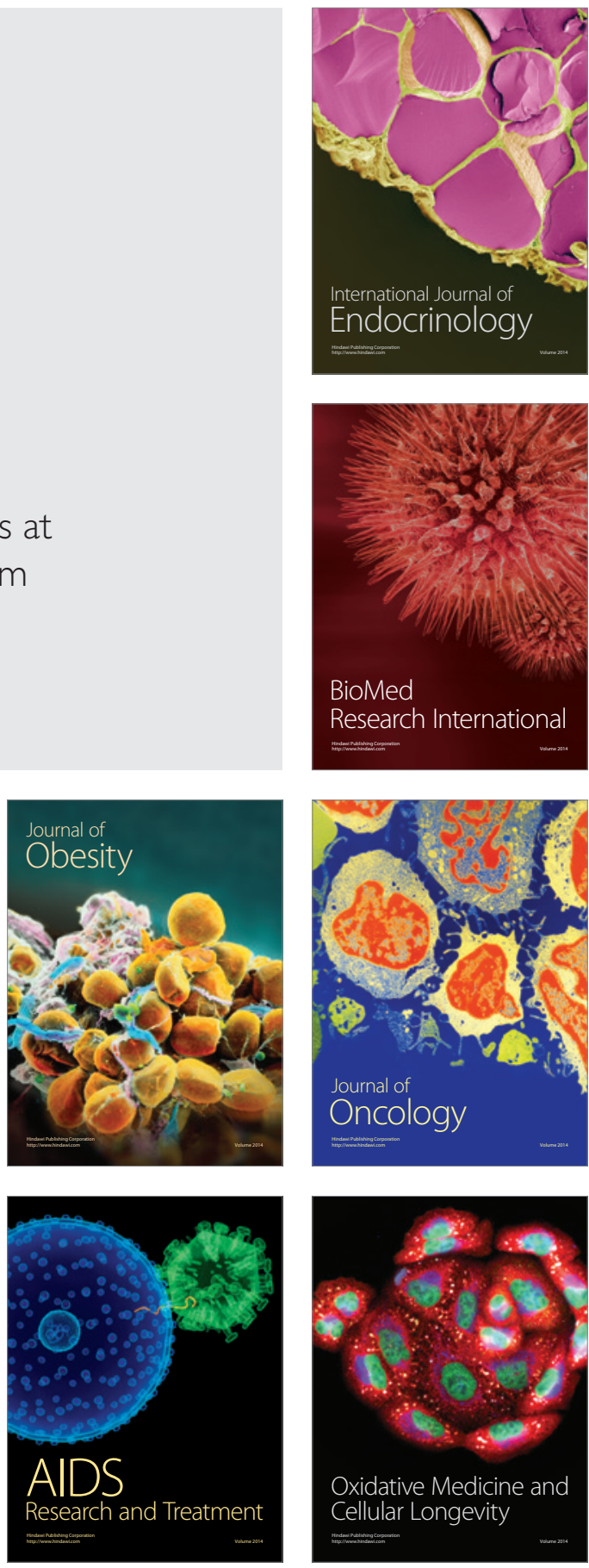